\title{
The Leadership Style Preference among Sabah
}

\section{Ethnicities}

\author{
Dg Kamisah A.B (Corresponding author) \\ Faculty of Business Management \\ P.O.Box 71, 88997 Kota Kinabalu, Sabah \\ Universiti Teknologi MARA \\ E-mail:dkamisah@yahoo.com \\ Syed Azizi Wafa \\ School of Business and Economics \\ Universiti Malaysia Sabah \\ E-mail: sazizi@ums.edu.my
}

Doi:10.5296/ijhrs.v4i1.5708

URL: http://dx.doi.org/10.5296/ijhrs.v4i1.5708

\begin{abstract}
Leadership style is not a novel concept and has been discussed widely all over the world. With the acceleration of globalization, organizations have to adapt to new paradigms or approaches of leadership. Therefore, it is important to understand leadership preference among individuals to ensure their willingness to perform their job. Specifically, this study was conducted to identify the relationship between gender, age, education level and working experience and leadership preference. This study intends to understand the leadership preference among Sabah communities which involve three major ethnic groups in Sabah namely Malay-Brunei, Bajau and Kadazan-Dusun. The sample of this research was selected based on purposive convenient sampling whereby all respondents are located in Kota Kinabalu. A questionnaire was administered for data collection with a sample of two hundred and nineteen employees from both the public and the private sectors. The data was analyzed using one way ANOVA and the results showed that the three major ethnic groups in Sabah appear to have similar leadership preference. In addition, no significant difference was found between leadership preferences and the demographic variables.
\end{abstract}

Keywords: Leadership, Preference, Ethnic, Demographic, Sabah.

\section{Introduction}

Leadership is often defined as a process of directing and influencing a group of people in an organization (Ivancevich et al, 2011). A good leader is one who is able to lead and motivate the employees to achieve organization's goals. Leadership had been exercised in many settings in businesses, governments, education and even sports. Therefore, it is extremely important that managers have a thorough understanding of what leadership entails. For instance, effective leadership is important to implement any changes successfully in organizations especially throughout the critical period and unexpected changes in the external 
environment (Littrell and Valentin, 2005).

Some people might misinterpret leadership as a dimension which is to lead any particular group. Leadership is not only about leading people, in fact it is about guiding the organization to achieve the desired goals. Specifically, it is about understanding where to go, how to get there and what to do to get there. Leadership is also about building good affiliation with the organizational members. Therefore, the question is whether or not a leader can bring the organizational members on board with their ideas. Basically, leaders will strive towards reaching the organizational goals together with their followers. Simply put, the success or failure of an organization depends on effective leadership. Employees will perceive their leader as effective from different perspective. Obviously, employees have their own preferences on the type of leader to lead them. This study is conducted in Sabah whereby it focused on three major ethnic groups namely Malay-Brunei, Bajau and Kadazan-Dusun.

The primary objective of this research is to determine the employees' preferences on leadership style among the three major ethnic groups of the Sabah population. Therefore, the research questions that will be answered are:

I. How do the Sabahans score on Path-Goal Leadership style?

II. Are there any significant differences in Leadership preferences among different demographic variables?

\section{Literature Review}

Leadership is defined as a process of social interactions in which leaders' attempts to influence their followers' behavior (Yukl, 2009). Another definition given by Stoner et al (1996), see leadership as a process of influencing any activities related to the work of group members. Similarly, Barrow (1977) refers to leadership as the behavioral process of influencing individuals or groups towards set goals. Better understanding on the concept of leadership is very crucial to an organization. Leadership can be considered as a charismatic influence which is used to inspire others (Peterson and Seligman, 2004). Leadership bonds workers together as well as to trigger employee motivation. Basically, leadership are grouped according to three main approachs namely trait approach (prior to the late 1940s), behavioral approach (late 1940s to late 1960s), and contingency approach (late 1960s to early 1980s).

The trait approach believes that leaders are born with certain leadership characteristics and they posse a similar trait (Ivancevich et al, 2011). In contrast to the trait approach, behavioral approach states that people can learn the characteristics of a leader (Ivancevich $e t$ $a l, 2011)$. Earliest behavioral approach concluded that effective leadership practices both task oriented and people oriented (Callahan et al, 2005). Finally, the contingency approach of leadership suggests that the appropriate style of leadership tend to vary according to the situational. In other words, contingency approach has to do with the principle that an effective leader is affected by the situation (Callahan et al, 2005). Path-goal theory focused more on providing enabling conditions for subordinate success and less on the situation or leader behavior (House, 1971). There are four leadership behaviors as identified by House (1971) namely directive, participative, supportive and achievement-oriented leader. House had reviewed and reformulated the theory in 1996 which address the effect of leaders on motivation and abilities of immediate subordinates. According to House (1996), this theory is 
concerned about the relationship between formally appointed superiors and subordinates in their day-to-day functioning.

\section{The study and Methodology}

This paper intends to identify the leadership preferences among three different ethnic groups in Sabah. Secondly, it will attempt to explore whether significant differences exist between the demographic variables on their leadership preferences of directive, supportive, participative and achievement style.

For the purpose of this study, the sample was selected based on purposive quota sampling. This research adopted the leadership instrument developed by Indvik (1988) which measures the superior-subordinate relationship. The original questionnaire was designed for leaders in order to identify their leadership style. However, the questionnaire has been modified to suit the context of this study which is to identify leadership style preference among employees. Meaning to say, the questionnaire was modified to measure the followers point of view regarding their leader. In other words, Indvik (1988) investigated from the leader perspective but this study intends to investigate from the followers' perspective. The questionnaire was modified and was translated into the Malay language in order to facilitate the needs of the sample population who are not proficient in English. A total of 270 questionnaires were distributed and 239 were returned from workers in the public and private sector in Kota Kinabalu, Sabah. However, only 219 questionnaires were valid and useable which shows that the returning rate of the study is $88.5 \%$ while the usable rate was $81 \%$.

\section{Result of the study}

\subsection{Reliability of Measures}

Based on the reliability analysis conducted, two out of four leadership styles scored more than 0.600 . The directive and supportive leadership style obtained a reliability score of less than 0.600 . However, both the directive and supportive variable was retained as it was essential in order to ascertain the leadership preference of respondents. Table 1 reports the results from reliability analysis for each leadership style.

Table 1: Reliability measures

\begin{tabular}{|l|c|}
\hline \multicolumn{1}{|c|}{ Variables } & Cronbach's Alpha \\
\hline Directive & .596 \\
\hline Supportive & .557 \\
\hline Participative & .746 \\
\hline Achievement Oriented & .680 \\
\hline
\end{tabular}

\subsection{Differences between Ethnic Groups on leadership preference}

The first research question was analyzed using the one way ANOVA. The table 2 reports the results from the ANOVA analysis. All variables score the significant value above 0.05 whereby it shows that there is no significant different among Malay-Brunei, Bajau and Kadazan-Dusun in leadership style preferences. 
Table 2: Differences between Ethnic Groups on leadership preference

\begin{tabular}{|l|r|r|r|}
\hline \multicolumn{1}{|c|}{ Directive } & \multicolumn{1}{c|}{ MEAN } & F-VALUE & \multicolumn{1}{c|}{ SIG } \\
\hline Malay-Brunei & & 0.079 & 0.924 \\
\hline Bajau & 3.2578 & & \\
\hline Kadazan-Dusun & 3.2325 & & \\
\hline \multicolumn{1}{|c|}{ Supportive } & 3.2581 & & \\
\hline Malay-Brunei & & 1.495 & 0.227 \\
\hline Bajau Participative & 3.1250 & & \\
\hline Kadazan-Dusun & 3.2473 & & \\
\hline \multicolumn{1}{|c|}{ Malay-Brunei } & 3.1211 & & \\
\hline Bajau & 3.0282 & & \\
\hline Kadazan-Dusun & 3.1102 & & \\
\hline \multicolumn{1}{|c|}{ Achievemenet-oriented } & & & \\
\hline Malay-Brunei & 3.0781 & & 0.773 \\
\hline Bajau & 3.1035 & & \\
\hline Kadazan-Dusun & 3.0693 & & \\
\hline
\end{tabular}

Table 3: Descriptive Statistic of Respondents Leadership Preferences

\begin{tabular}{|l|l|r|r|}
\hline \multicolumn{1}{|c|}{$\begin{array}{c}\text { Leadership } \\
\text { Preference }\end{array}$} & \multicolumn{1}{|c|}{ Ethnics } & \multicolumn{1}{c|}{ Count } \\
\hline Directive & Malay-Brunei & 18 & 28.1 \\
\hline & Bajau & 17 & 27.4 \\
\hline & Kadazan-Dusun & 46 & 49.5 \\
\hline Supportive & Malay-Brunei & 17 & 26.6 \\
\hline & Bajau & 19 & 30.6 \\
\hline & Kadazan-Dusun & 25 & 26.9 \\
\hline Participative & Malay-Brunei & 14 & 21.9 \\
\hline & Bajau & 9 & 14.5 \\
\hline & Kadazan-Dusun & 13 & 13.9 \\
\hline Achievement Oriented & Malay-Brunei & 15 & 23.4 \\
\hline & Bajau & 17 & 27.4 \\
\hline & Kadazan-Dusun & 9 & 9.7 \\
\hline
\end{tabular}

\subsection{Demographic Variables and Leadership Preference}

Significant differences between demographic variables and leadership preference was analyzed using the t-test. Table 3 reports the results from the t-test analysis. From the table, the result of the t-test indicates that no significant differences were found between the gender, age groups, education and working experience on the leadership style of directive, supportive, 
participative and achievement-oriented.

Table 4: Differences on Leadership Preference

\begin{tabular}{|c|c|c|c|c|}
\hline \multirow{3}{*}{ Leadership preference } & \multirow{2}{*}{\multicolumn{2}{|c|}{$\begin{array}{c}\text { Mean } \\
\text { Gender }\end{array}$}} & \multirow{3}{*}{ t-value } & \multirow{3}{*}{ Sig } \\
\hline & & & & \\
\hline & Male & Female & & \\
\hline Directive & 3.2696 & 3.2423 & 0.085 & 0.660 \\
\hline Supportive & 3.2096 & 3.2086 & 0.896 & 0.989 \\
\hline Participative & 3.0478 & 3.1093 & 0.268 & 0.375 \\
\hline \multirow[t]{3}{*}{ Achievement Oriented } & 3.1091 & 3.0513 & 0.618 & 0.423 \\
\hline & \multicolumn{2}{|r|}{ Age } & \multirow{2}{*}{ t-value } & \multirow{2}{*}{ Sig } \\
\hline & Young & Old & & \\
\hline Directive & 3.2328 & 3.2664 & 3.276 & 0.561 \\
\hline Supportive & 3.2304 & 3.1902 & 3.571 & 0.523 \\
\hline Participative & 3.1176 & 3.0662 & 5.601 & 0.424 \\
\hline \multirow[t]{3}{*}{ Achievement Oriented } & 3.0678 & 3.0705 & 5.530 & 0.968 \\
\hline & \multicolumn{2}{|c|}{ Education Level } & \multirow{2}{*}{ t-value } & \multirow{2}{*}{ Sig } \\
\hline & Graduate & Non-Graduate & & \\
\hline Directive & 3.1754 & 3.2840 & 0.008 & 0.081 \\
\hline Supportive & 3.2164 & 3.2056 & 0.306 & 0.874 \\
\hline Participative & 3.0672 & 3.1003 & 1.046 & 0.634 \\
\hline \multirow[t]{3}{*}{ Achievement Oriented } & 3.0560 & 3.0751 & 0.683 & 0.791 \\
\hline & \multicolumn{2}{|c|}{ Working Experience } & \multirow{2}{*}{ t-value } & \multirow{2}{*}{ Sig } \\
\hline & Less & More & & \\
\hline Directive & 3.2304 & 3.2685 & 0.180 & 0.508 \\
\hline Supportive & 3.2549 & 3.1688 & 1.264 & 0.171 \\
\hline Participative & 3.1201 & 3.0641 & 2.455 & 0.383 \\
\hline Achievement Oriented & 3.0580 & 3.0791 & 1.918 & 0.753 \\
\hline
\end{tabular}

\section{Discussion and Conclusion}

The profile of the respondents shows that 68 were males and 151 were females. The results of this study found that there was no significant difference among Malay-Brunei, Bajau and Kadazan-Dusun on the leadership style preferences. This finding contradicted with those of House (1995) who claims that individuals in various ethnic groups may view leadership in different ways. However, the finding of this study might differ from House (1995) because these three different ethnic groups in Sabah might be sharing the same values and beliefs. Additionally, Wood and Jogulu (2006) claim that the concept of leadership tends to differ across cultures because of the variations which exist in that particular culture.

Although no significant differences were found among Malay-Brunei, Bajau and Kadazan-Dusun on the leadership preferences, the proportion of preference among them is quite different. Malay-Brunei and Bajau appear to have least prefer the participative 
leadership style while Kadazan-Dusun appear to have least prefer the achievement-oriented leadership style. The finding based on the descriptive statistics revealed that the ethnic groups of Malay-Brunei and Kadazan-Dusun preferred directive leadership style while the Bajau prefer the supportive style. Therefore, it can be concluded that their leadership style preferences are somewhat different. In addition, the study conducted by Roselina, Syed, and Yusoff (2002) revealed that Indian and Malay managers' preference are on the participating leadership style while Chinese managers' preference is more on delegating leadership style. Though the theory of leadership is different for both study, the study by Roselina, Syed, and Yusoff (2002) revealed that there are also differences in terms of leadership preferences as well among the three ethnic groups in peninsular Malaysia.

In addition, the findings of this study also revealed that there are no significant differences on leadership style preferences among Malay-Brunei, Bajau and Kadazan-Dusun based on the different demographic variables namely gender, age, level of education and working experience. Similarly, previous studies conducted by Yusoff (1999) found that there was no significant relationship between age and telling, selling, participating and delegating leadership style. It is clear that employees tend to have same preferences on leadership style no matter they are male or female, young or old, graduate or non-graduate as well as having less or more working experience. Further studies can be conducted in order to confirm the results found in this study.

\section{References}

Barrow, J.C. 1977. The variables of leadership: a review and conceptual framework, Academy Management Review, April, pp. 231-51.

Callahan, J.L., Hasler, M.G., and Tolson, H 2005. Perceptions of emotion expressiveness: gender differences among senior executives. Leadership and organization development journal. Vol 26 No.7, pp. 512-528.

House, R.J. 1971. A Path-goal Theory of leader effectiveness. Administrative Science Quarterly, Vol. 16, pp. 321-328.

House, R.J. 1995. Leadership in 21st century: a speculative inquiry, in Howard, A. (Ed.), The Changing Nature of Work, Jossey-Bass, San Francisco, CA.

House, R.J. 1996. Path-Goal theory of leadership: Lessons, legacy and a Reformulated theory. Leadership Quarterly, Vol. 7 No. 3 pp. 323-352.

Indvik, J. 1988. A Path-Goal Theory investigation of superior subordinate relationship. Unpublished Doctoral Dissertation, University of Wisconsin-Madison.

Ivancevich, J.M., Konopaske, R. and Matteson, M.T. 2011. Organizational Behavior and Management, $9^{\text {th }}$ Edition, McGraw Hill, New York, NY.

Littrell, R.F. and Valentin, L.N. 2005. Preferred leadership behaviours: exploratory results from Romania, Germany, and the UK. Journal of Management Develoment, Vol. 24 No.5, pp. 421-442.

Peterson, C. and Seligman, M.E.P. 2004. Character Strengths and Virtues: A Handbook and Classification, American Psychological Association, Washington, DC. 


\section{Macrothink

Roselina A. Saufi, Syed Azizi Wafa \& Mohd Yusoff Zainun. 2002. "Leadership Style Preference of Malaysian Managers". Malaysian Management Review, vol. 37, no 1, June,pp1-10

Stoner JA., Freeman FE., Gilbert DR. 1996. Management (translation). Jakarta: Prenhallindo.

Wood, G. and Jogulu, U. 2006. Malaysian and Australian male and female middle managers: a cross-cultural comparison of workplace attitudes, aspirations for promotion, and self-rated leadership styles. International Journal of Knowledge, Culture and Change Management, Vol. 6, pp. 109-19.

Yukl, G. 2009. Leadership in Organizations, 7th ed., Prentice-Hall, Upper Saddle River, NJ.

Yusoff, Hamzah. 1999. The impact of demography factors and culture on leadership preference among Malaysian managers. Unpublished Master Dissertation. School of management, USM. 